\title{
Enterprise budgets of some greenhouse vegetable crops in Saudi Arabia
}

\author{
A. M. Al-Abdulkader
}

\author{
King Abdulaziz City for Science and Technology, Saudi Arabia
}

\begin{abstract}
Enterprise budgets that could be served as a guide to the local entrepreneurs are estimated for seven popular greenhouse vegetable crops grown in Saudi Arabia. The selected crops are tomatoes, cucumbers, green peppers, eggplant, okra, beans, and squash. The estimated enterprise budgets are based on the best and most accurate estimates on returns and costs available in the year 2000 for some specialized greenhouse vegetable enterprises in Saudi Arabia. Breakeven analysis for prices and crop production is applied on the selected crops to show the possible range of reduction in prices per ton and crop production in which the enterprises are to breakeven. Results of the study showed a desirable enterprise environment of the selected crops in Saudi Arabia. Tomatoes and cucumbers are the most profitable greenhouse enterprises, generating about 160.9 thousand SR/ha. for tomatoes and about 155.5 thousand SR/ha. for cucumbers, whereas, okra and eggplant generate the least net returns out of the selected crops, about 5.3 and 9.6 thousand SR/ha. respectively. Results showed, also, the wide range of reduction in prices per ton and crop production in which the enterprises are to breakeven, ranging between a minimum of $4 \%$ for okra and a maximum of $51 \%$ for cucumbers.
\end{abstract}

Key words: breakeven analysis, enterprise budgets, greenhouses, vegetable crops.

\section{ميزليلتمشاريع بهض محامل الخضر المحمية في المملكة العربية اللهعونية}

\section{ألحمد بن محمد العبد القالر}

\section{مدينة المك عبدالهزبز لالملوه والقنية، الممكة العربية السهوبية}

الملاص: تهوف هذه الدرلمة إلى ققدير ميزانيك مشاريع زراعة بعض محاصل الخضر المحمية بالمملكة العربية

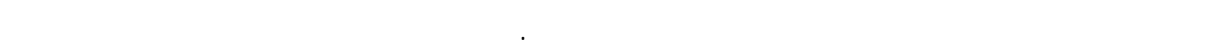

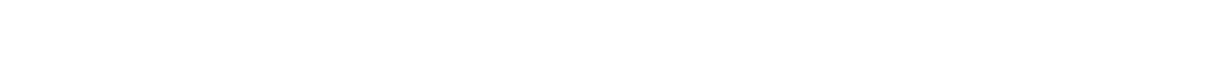

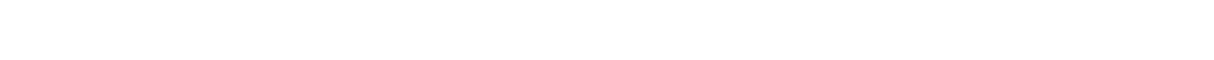

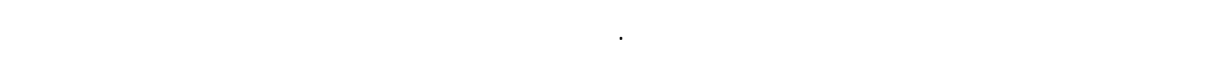
(Breakeven Analysis)

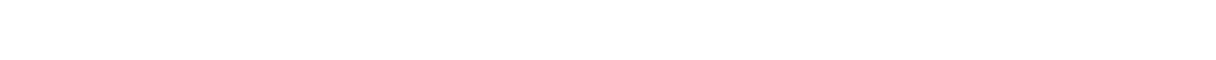

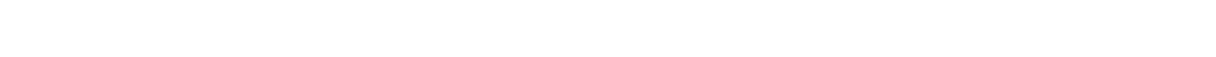

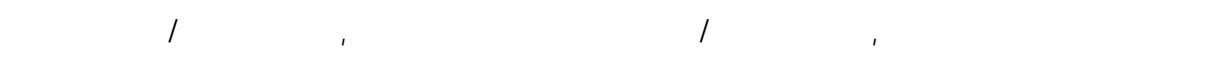

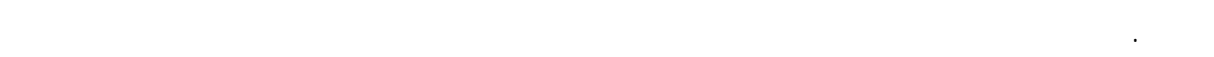

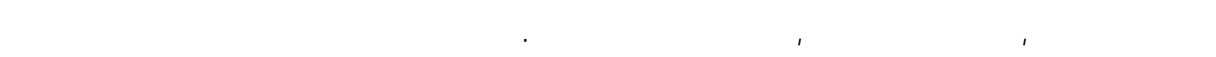

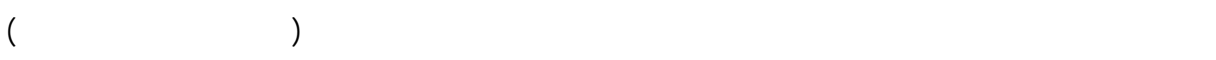

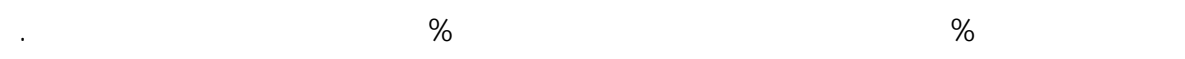
الهاملت الففتلحية : تحليل التعال، ميزانيت المشاريع، بيوت محمية، محاصل الخضر. 


\section{Introduction}

Greenhouse use in agriculture is a favorable and promising investment in Saudi Arabia. Realizing its potential productivity and efficient water use, Saudi Arabia pays a great attention towards expanding the use of greenhouse in agriculture. Accordingly, the specialized greenhouse enterprises have increased throughout the last two decades more than twice number-wise and more than eighteen times production-wise. Greenhouse projects jumped from 104 enterprises producing about 26 thousand tons in 1984 to 295 enterprises producing about 142 thousand tons in 1999. Greenhouse produced vegetables represent about $42 \%$ of the total vegetable production in Saudi Arabia. Tomatoes and cucumbers are the leading greenhouse vegetable crops grown in Saudi Arabia, representing more than 85 $\%$ out of the overall greenhouse production in 1999 (Ministry of Agriculture and Water, 2001a,b). Figure 1 illustrates the open field versus the greenhouse vegetable production in Saudi Arabia throughout years $1995-2000$.
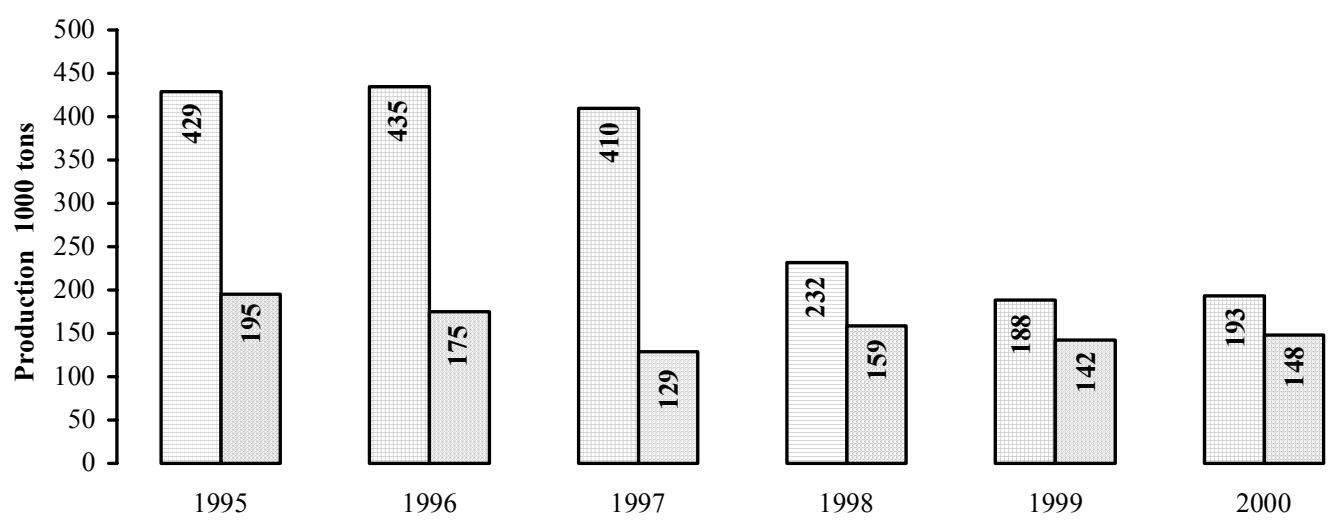

$\square$ Open field production $\square$ Greenhouse production

\section{Figure 1. Opened Field vs. Greenhouse Vegetables Production in Saudi Arabia}

The main objective of this paper is to estimate enterprise budgets of some popular greenhouse vegetable crops in Saudi Arabia, namely, tomatoes, cucumbers, green peppers, eggplant, okra, beans, and squash, and this could work out as a guide to the local entrepreneurs.

Enterprise budgets represent estimates of returns, costs, and net returns associated with the production activities of crops and livestock enterprises. Such information is highly valued to farm producers and entrepreneurs, extension specialists, governmental agencies, and decision makers. Enterprise budgets are used mainly to itemize returns of an enterprise's products and costs of inputs required for production activities; evaluate enterprise efficiency; estimate benefits and costs for major changes in production activities; provide the basis for a total farm plan; and provide non-farmers with costs incurred in producing crops and livestock (Greaser and Harper, 1994). Enterprise budgets could serve as a management and decision making guide for current and prospective entrepreneurs of such enterprises (Powers, et al., 1998). Working on a farm level, enterprise budgets are desirable as an estimate of returns and costs for the same farm. However, the enterprise budgets should reflect average or typical conditions when working on national or regional level (Kletke, 1989). 


\section{Material and Methods}

This study represents estimates of enterprise budgets for three specialized greenhouse vegetable enterprises in Saudi Arabia. Such estimates are based on the best and most accurate estimation on returns and costs available in the year 2000. Seven greenhouse vegetable crops grown in Saudi Arabia are selected in this study, based on profitability to growers and preferences local consumers. The selected crops are tomatoes, cucumbers, green peppers, eggplant, okra, beans, and squash. Estimates are represented in terms of Saudi Riyals (SR) per hectare (ha). Each hectare consists of 43 greenhouses, with total area of about 220 square meters per house. Production season of the selected crops is taken into account in the estimated enterprise budgets as it affects the level of production, costs, and returns. Production season of the selected crops varies between 10 months for tomatoes, green peppers, and eggplant, 7 months for cucumbers and beans, and 6 months for okra and squash.

Breakeven analysis for prices and crop production is performed for the selected crops. Breakeven analysis is a useful farm management tool, as it allows calculation of various combinations of price and production that will cover anticipated costs, and could be used to calculate the breakeven price or production required to cover variable costs. The breakeven price computes the minimum price per unit required to cover all costs at the anticipated production, whereas, the breakeven production is used to compute the minimum production required to cover all costs at the anticipated price per unit. The breakeven price and production could be expressed in the following forms (Greaser and Harper, 1994):

Breakeven price $=$ anticipated total costs $\div$ anticipated production.

Breakeven production $=$ anticipated total costs $\div$ anticipated price.

\section{Results and Discussions}

Tables 1 to 7 illustrate the per hectare enterprise budgets of the selected greenhouse vegetable crops in Saudi Arabia. Each table consists of four sections. These sections are gross returns, variable costs, fixed costs, and net returns. 
Table 1. Estimated Enterprise Budget Per Hectare of Greenhouse Tomatoes in Saudi Arabia $^{1}$, Year 2000

\begin{tabular}{|c|c|c|c|c|}
\hline Item & Unit & $\begin{array}{l}\text { Price or Cost } /^{2} \text { unit } \\
\text { (SR) }\end{array}$ & Quantity $^{r}$ & $\begin{array}{l}\text { Value } \\
\text { (SR/ha) }\end{array}$ \\
\hline \multicolumn{5}{|l|}{ Gross Returns } \\
\hline & Ton & 2000 & 168 & 336312.85 \\
\hline \multicolumn{5}{|l|}{ Variable Costs } \\
\hline Fertilizer & $\mathrm{kg}$ or lit. & 2 & 12900 & 25800 \\
\hline Seed \& G7 & Pack & 315 & 26 & 8323.74 \\
\hline Labor & Hour & 2 & 18447 & 36894 \\
\hline Water & $\mathrm{Cm}$ & 0.40 & 17028 & 6811.20 \\
\hline Pesticides & $\mathrm{kg}$ or lit & 1 & 12900 & 12900 \\
\hline Repairs & House & 360 & 43 & 15480 \\
\hline Electricity & k. wt. & 0.12 & 28131 & 3375.75 \\
\hline Packing & $5 \mathrm{~kg}$ pack & 0.50 & 33631 & 16815.64 \\
\hline Hauling & Trip & 150 & 183 & 27412.50 \\
\hline \multirow{2}{*}{\multicolumn{5}{|c|}{ Fixed Costs }} \\
\hline & & & & \\
\hline Depreciation & House & 501.42 & 43 & 21561.25 \\
\hline Total Fixed Costs & SR/ha & & & 21561.25 \\
\hline Total Costs & SR/ha & & & 175374.09 \\
\hline Net Returns & SR/ha & & & 160938.76 \\
\hline
\end{tabular}

1. Production season lasts for 10 months.

2. $1 \$=3.75 \mathrm{SR}$

3. Values are rounded.

Gross returns of the selected greenhouse enterprises are the product of the average seasonal production per hectare and the prevailing market prices per ton of the products. Results showed that the calculated gross returns of the selected greenhouse vegetable crops range between a minimum of about SR 5.300 per hectare (SR/ha.) of okra to a maximum of about SR 16.900 ha., of tomatoes.

Costs of the selected greenhouse vegetable include several components reflecting variable and fixed costs.
Variable costs include expenses of all varying inputs used to produce the products. Examples include expenses for fertilizers, seeds, pesticides, water, labor, electricity, marketing, and repairs. Variable costs of the selected enterprises range between about SR 92.300. of squash to about SR 158.300. of green peppers. Expenses of marketing including packing and hauling, labor, and fertilizer are the major components of the variable costs, representing on an average basis around $25 \%, 24 \%$, and $17 \%$, respectively. 
Table 2. Estimated Enterprise Budget Per Hectare of Greenhouse Cucumbers in Saudi

\begin{tabular}{|c|c|c|c|c|}
\hline \multicolumn{5}{|c|}{ Arabia $^{1}$, Year 2000} \\
\hline Item & Unit & $\begin{array}{l}\text { Price or Cost/unit } \\
(\mathrm{SR})^{2}\end{array}$ & Quantity $^{r}$ & $\begin{array}{l}\text { Value } \\
\text { (SR/ha) }\end{array}$ \\
\hline \multicolumn{5}{|l|}{ Gross Returns } \\
\hline & Ton & 2000 & 154 & 307142.86 \\
\hline \multicolumn{5}{|l|}{ Variable Costs } \\
\hline Fertilizer & $\mathrm{kg}$ or lit. & 2 & 9030 & 18060 \\
\hline Seed \& G7 & Pack & 635 & 26 & 16254 \\
\hline Labor & Hour & 2 & 12913 & 25825 \\
\hline Water & $\mathrm{Cm}$ & 0.40 & 11920 & 4767.84 \\
\hline Pesticides & $\mathrm{kg}$ or lit & 1 & 9030 & 9030 \\
\hline Repairs & House & 360 & 43 & 15480 \\
\hline Electricity & k. wt. & 0.12 & 28131 & 3375.75 \\
\hline Packing & $5 \mathrm{~kg}$ pack & 0.50 & 30714 & 15357.14 \\
\hline Hauling & Trip & 150 & 146 & 21930 \\
\hline Total Variable Costs & SR/ha & & & 130080.53 \\
\hline \multicolumn{5}{|l|}{ Fixed Costs } \\
\hline Depreciation & House & 501.42 & 43 & 21561.25 \\
\hline Total Fixed Costs & SR/ha & & & 21561.25 \\
\hline Total Costs & SR/ha & & & 151641.79 \\
\hline Net Returns & SR/ha & & & 155501.07 \\
\hline
\end{tabular}

${ }^{1}$ Production season lasts for 7 months.

${ }^{2} 1 \$=3.75 \mathrm{SR}$

${ }^{3}$ Values are rounded.

Table 3. Estimated Enterprise Budget Per Hectare of Greenhouse Green Peppers in Saudi Arabia ${ }^{1}$, Year 2000

\begin{tabular}{clccc}
\hline \multicolumn{1}{c}{ Item } & \multicolumn{1}{c}{ Unit } & $\begin{array}{c}\text { Price or Cost/unit } \\
\text { (SR) }\end{array}$ & Quantity $^{\mathbf{3}}$ & $\begin{array}{c}\text { Value } \\
\text { (SR/ha) }\end{array}$ \\
\hline Gross Returns & Ton & 2000 & 134 & 267555.56 \\
Variable Costs & & & & \\
Fertilizer & kg or lit. & 2 & 12900 & 25800 \\
Seed \& G7 & Pack & 635 & 26 & 16254 \\
Labor & Hour & 2 & 18447 & 36894 \\
Water & Cm & 0.40 & 17028 & 6811.20 \\
Pesticides & kg or lit & 1 & 12900 & 12900 \\
Repairs & House & 360 & 43 & 15480 \\
Electricity & k. wt. & 0.12 & 28131 & 3375.75 \\
Packing & 5 kg pack & 0.50 & 26756 & 13377.78 \\
Hauling & Trip & 150 & 183 & 27412.50 \\
Total Variable Costs & SR/ha & & & $\mathbf{1 5 8 3 0 5 . 2 3}$ \\
Fixed Costs & & & 43 & 21561.25 \\
Depreciation & House & 501.42 & & $\mathbf{2 1 5 6 1 . 2 5}$ \\
Total Fixed Costs & SR/ha & & & $\mathbf{1 7 9 8 6 6 . 4 8}$ \\
Total Costs & SR/ha & & & \\
Net Returns & SR/ha & & & \\
\hline
\end{tabular}

${ }^{1}$ Production season lasts for 10 months.

${ }^{2} 1 \$=3.75$ SR

${ }^{3}$ Values are rounded. 
Fixed costs include expenses of all non varying inputs required for the production process. Examples include depreciation of the complete greenhouse module. The complete greenhouse module of the on hand enterprise consists of an around 220 square meters plastic cool tunnel. heavy duty galvanized frames, covered with fiberglass both front and back, a plastic double wall of 7\% U.V. 200 micron, an blower to inflate plastic sheets, 21.5 horse power fans of capacity 43000 $\mathrm{cm} / \mathrm{hr}$ cooling pads a with total area of 12 $\mathrm{m}^{2}$, a water pump, automatic control systems, and a five line drip irrigation system (Nafa, 2002). The annual depreciation expenses for the greenhouse module are estimated at about SR 21.560, assuming a 30 years life expectation of the greenhouse module. Total costs are the sum of both cost components, variable and fixed costs.

Net returns of the selected enterprises were obtained through deducting the total costs from the gross returns for each crop. The enterprise gross returns should cover the variable costs in the short run to be able to continue. However, if fixed costs are not covered in the long run, reinvestments in capital items such as greenhouse modules cannot be made and existing capital eventually is depleted (Greaser and Harper, 1994). Results for the selected greenhouse vegetable crops in Saudi Arabia showed the promising entrepreneur environment for such enterprises, generating positive net returns covering all the expenses in the short and long runs. Based on the net returns figures, tomatoes and cucumbers are the most profitable greenhouse enterprises in Saudi Arabia, generating about SR 160.900 for tomatoes and about SR 155.500 for cucumbers. However, okra and eggplant crops would generate the least net returns out of the selected crops, SR 5.300 and SR 9.600 thousand SR/ha. respectively.

Table 4. Estimated Enterprise Budget Per Hectare of Greenhouse Eggplant in Saudi Arabia ${ }^{1}$, Year 2000

\begin{tabular}{|c|c|c|c|c|}
\hline Item & Unit & $\begin{array}{l}\text { Price or Cost/unit } \\
(\mathrm{SR})^{2}\end{array}$ & Quantity $^{r}$ & $\begin{array}{l}\text { Value } \\
\text { (SR/ha) }\end{array}$ \\
\hline \multicolumn{5}{|l|}{ Gross Returns } \\
\hline & Ton & 1800 & 97 & 174150 \\
\hline \multicolumn{5}{|l|}{ Variable Costs } \\
\hline Fertilizer & $\mathrm{kg}$ or lit. & 2 & 12900 & 25800 \\
\hline Seed \& G7 & Pack & 180 & 26 & 4644 \\
\hline Labor & Hour & 2 & 18447 & 36894 \\
\hline Water & $\mathrm{Cm}$ & 0.40 & 17028 & 6811.20 \\
\hline Pesticides & $\mathrm{kg}$ or lit & 1 & 12900 & 12900 \\
\hline Repairs & House & 360 & 43 & 15480 \\
\hline Electricity & k. wt. & 0.12 & 28131 & 3375.75 \\
\hline Packing & $5 \mathrm{~kg}$ pack & 0.50 & 19350 & 9675 \\
\hline Hauling & Trip & 150 & 183 & 27412.50 \\
\hline \multirow{2}{*}{\multicolumn{5}{|c|}{ Fixed Costs }} \\
\hline & & & & \\
\hline Depreciation & House & 501.42 & 43 & 21561.25 \\
\hline Total Fixed Costs & SR/ha & & & 21561.25 \\
\hline Total Costs & SR/ha & & & 164553.70 \\
\hline Net Returns & SR/ha & & & 9596.30 \\
\hline
\end{tabular}


Table 5. Estimated Enterprise Budget Per Hectare of Greenhouse Squash in Saudi Arabia $^{1}$, Year 2000

\begin{tabular}{clccc}
\hline \multicolumn{1}{c}{ Item } & \multicolumn{1}{c}{ Unit } & $\begin{array}{c}\text { Price or Cost/unit } \\
\text { (SR) }\end{array}$ & Quantity $^{\mathbf{r}}$ & $\begin{array}{c}\text { Value } \\
\text { (SR/ha) }\end{array}$ \\
\hline Gross Returns & Ton & 2000 & & \\
Variable Costs & & & 86 & 172000 \\
Fertilizer & kg or lit. & 2 & 7740 & 15480 \\
Seed \& G7 & Pack & 100 & 9 & 860 \\
Labor & Hour & 2 & 11051 & 22102 \\
Water & Cm & 0.40 & 10191 & 4076.40 \\
Pesticides & kg or lit & 1 & 7740 & 7740 \\
Repairs & House & 360 & 43 & 15480 \\
Electricity & k. wt. & 0.12 & 28131 & 3375.75 \\
Packing & 5 kg pack & 0.50 & 17200 & 8600 \\
Hauling & Trip & 150 & 97 & 14620 \\
Total Variable Costs & SR/ha & & & $\mathbf{9 2 3 3 4 . 1 5}$ \\
Fixed Costs & & & 43 & 21561.25 \\
Depreciation & House & 501.42 & & $\mathbf{2 1 5 6 1 . 2 5}$ \\
Total Fixed Costs & SR/ha & & & $\mathbf{1 1 3 8 9 5 . 4 0}$ \\
Total Costs & SR/ha & & & $\mathbf{5 8 1 0 4 . 6 0}$ \\
Net Returns & SR/ha & & & \\
\hline
\end{tabular}

${ }^{1}$ Production season lasts for 6 months.

${ }^{2} 1 \$=3.75 \mathrm{SR}$

${ }^{3}$ Values are rounded.

Table 6. Estimated Enterprise Budget Per Hectare of Greenhouse Beans in Saudi Arabia ${ }^{1}$, Year 2000

\begin{tabular}{llccc}
\hline \multicolumn{1}{c}{ Item } & \multicolumn{1}{c}{ Unit } & $\begin{array}{c}\text { Price or Cost/unit } \\
\text { (SR) }\end{array}$ & Quantity $^{\mathbf{3}}$ & $\begin{array}{c}\text { Value } \\
\text { (SR/ha) }\end{array}$ \\
\hline Gross Returns & Ton & 4000 & 51 & 203143.61 \\
Variable Costs & & & & \\
Fertilizer & kg or lit. & 2 & 9030 & 18060 \\
Seed \& G7 & Pack & 180 & 24 & 4300 \\
Labor & Hour & 2 & 12913 & 25825.80 \\
Water & Cm & 0.40 & 11920 & 4767.84 \\
Pesticides & kg or lit & 1 & 9030 & 9030 \\
Repairs & House & 360 & 43 & 15480 \\
Electricity & k. wt. & 0.12 & 28131 & 3375.75 \\
Packing & 5 kg pack & 0.50 & 10157 & 5076.59 \\
Hauling & Trip & 150 & 122 & 18275 \\
Total Variable Costs & SR/ha & & & $\mathbf{1 0 4 1 9 2 . 9 8}$ \\
Fixed Costs & & & 43 & 21561.25 \\
Depreciation & House & 501.42 & & $\mathbf{2 1 5 6 1 . 2 5}$ \\
Total Fixed Costs & SR/ha & & & $\mathbf{1 2 5 7 5 4 . 2 3}$ \\
Total Costs & SR/ha & & & $\mathbf{7 7 3 8 9 . 3 8}$ \\
Net Returns & SR/ha & & & \\
\hline
\end{tabular}

${ }^{1}$ Production season lasts for 7 months.

${ }^{2} 1 \$=3.75 \mathrm{SR}$

${ }^{3}$ Values are rounded. 
Table 7. Estimated Enterprise Budget Per Hectare of Greenhouse Okra in Saudi Arabia ${ }^{1}$, Year 2000

\begin{tabular}{|c|c|c|c|c|}
\hline Item & Unit & $\begin{array}{c}\text { Price or Cost/unit } \\
\text { (SR) })^{2}\end{array}$ & Quantity $^{r}$ & $\begin{array}{c}\text { Value } \\
\text { (SR/ha) }\end{array}$ \\
\hline \multicolumn{5}{|l|}{ Gross Returns } \\
\hline & Ton & 8000 & 16 & 125090.87 \\
\hline \multicolumn{5}{|l|}{ Variable Costs } \\
\hline Fertilizer & $\mathrm{kg}$ or lit. & 2 & 9030 & 18060 \\
\hline Seed \& G7 & Pack & 40 & 47 & 1892 \\
\hline Labor & Hour & 2 & 12913 & 25825.80 \\
\hline Water & $\mathrm{Cm}$ & 0.40 & 11920 & 4767.84 \\
\hline Pesticides & $\mathrm{kg}$ or lit & 1 & 9030 & 9030 \\
\hline Repairs & House & 360 & 43 & 15480 \\
\hline Electricity & k. wt. & 0.12 & 28131 & 3375.75 \\
\hline Packing & $5 \mathrm{~kg}$ pack & 0.50 & 3127 & 1563.64 \\
\hline Hauling & Trip & 150 & 122 & 18275 \\
\hline Total Variable Costs & SR/ha & & & 98270.03 \\
\hline \multicolumn{5}{|l|}{ Fixed Costs } \\
\hline Depreciation & House & 501.42 & 43 & 21561.25 \\
\hline Total Fixed Costs & SR/ha & & & 21561.25 \\
\hline Total Costs & SR/ha & & & 119831.28 \\
\hline Net Returns & SR/ha & & & 5259.59 \\
\hline
\end{tabular}

${ }^{1}$ Production season lasts for 6 months.

${ }^{2} 1 \$=3.75 \mathrm{SR}$

${ }^{3}$ Values are rounded.

The breakeven analysis for prices and production of the selected crops is shown in Table 8. Results showed the possible range of reduction in prices per ton and crop production in which the enterprises are to breakeven, ranging between a minimum of $4 \%$ for okra and a maximum of $51 \%$ for cucumbers.

Table 8. The Breakeven Analysis for Prices and Productions of the Selected Greenhouse Vegetable Crops in Saudi Arabia, Year 2000.

\begin{tabular}{|c|c|c|c|c|c|c|}
\hline Crop & $\begin{array}{c}\text { Market } \\
\text { Price } \\
\text { (SR/ton) }{ }^{1} \\
\end{array}$ & $\begin{array}{c}\text { Breakeven } \\
\text { Price } \\
\text { (SR/ton) } \\
\end{array}$ & $\begin{array}{c}\text { Difference } \\
(\%)\end{array}$ & $\begin{array}{c}\text { Average } \\
\text { Production } \\
\text { (ton/ha) } \\
\end{array}$ & $\begin{array}{c}\text { Breakeven } \\
\text { Production } \\
(\text { ton } / \text { ha })\end{array}$ & $\begin{array}{c}\text { Difference } \\
(\%)\end{array}$ \\
\hline Tomatoes & 2000 & 1043 & 48 & 168 & 88 & 48 \\
\hline Cucumbers & 2000 & 987 & 51 & 154 & 76 & 51 \\
\hline Green Pepper & 2000 & 1345 & 33 & 134 & 90 & 33 \\
\hline Egg Plants & 1800 & 1701 & 6 & 97 & 91 & 6 \\
\hline Squash & 2000 & 1324 & 34 & 86 & 57 & 34 \\
\hline Beans & 4000 & 2476 & 38 & 51 & 31 & 38 \\
\hline Okra & 8000 & 7664 & 4 & 16 & 15 & 4 \\
\hline
\end{tabular}

\section{Summary and Conclusions}

Enterprise budgets were estimated for seven popular greenhouse vegetable crops grown in Saudi Arabia, showing a profitable entrepreneur environment, and a possibility of enhancing the expansion of greenhouse enterprises in Saudi Arabia.
Results showed that tomatoes are the most profitable greenhouse enterprise in Saudi Arabia, among the various selected vegetable crops, generating about SR 160.900. However, okra was the least profitable vegetable crop among the selected crops, generating about SR 5.300. Breakeven analysis showed the wide range 
of reduction in prices per ton and crop production for which the enterprises are to breakeven, ranging between a minimum of $4 \%$ for okra and a maximum of $51 \%$ for cucumbers.

\section{Acknowledgment}

Deep appreciation is expressed to Saleh Alhenaky Enterprises of Saudi Arabia for their great assistance towards pursuing this study.

\section{References}

Greaser, G. L. and J. K. Harper. 1994. Enterprise Budget Analysis. Penn. State University, College of Agricultural Sciences. Cooperative Extension.

Kletke, D. 1989. Enterprise Budgets. In: Luther Tweeten. (Ed.), Agricultural Policy Analysis Tools for Economic Development. Ohio State Univ. pp. 196-206.
Ministry of Agriculture and Water. 1988. Agriculture Statistical Year Book. 5. Saudi Arabia.

Ministry of Agriculture and Water. 2000. Agriculture Statistical Year Book. 12. Saudi Arabia.

Ministry of Agriculture and Water. 2001a. Agriculture Statistical Year Book. 13. Saudi Arabia.

Ministry of Agriculture and Water. 2001b. Indicators for Agriculture and Water. Saudi Arabia.

Nafa Metal Works Factory, a Division of Nafa Enterprises Ltd., 2002, Saudi Arabia.

Powers, L., I. Steve, W. Tim, T. Richard, S. John, R. Brent, S. Dave, J. Terry and D. Winston. 1998. Horticulture Crop Enterprise Cost and Return Estimates for 1998. University of Kentucky. 